\title{
Measuring Exercise-Induced Secreted Protein Acidic and Rich in Cysteine Expression as a Molecular Tool to Optimize Personalized Medicine
}

\author{
Abdelaziz Ghanemi ${ }^{1,2}$, Mayumi Yoshioka ${ }^{1}$ (D) and Jonny St-Amand ${ }^{1,2, *(\mathbb{D})}$ \\ 1 Functional Genomics Laboratory, Endocrinology and Nephrology Axis, CHU de Québec-Université Laval \\ Research Center, Québec, QC G1V 4G2, Canada; abdelaziz.ghanemi@crchudequebec.ulaval.ca (A.G.); \\ mayumi.yoshioka@crchudequebec.ulaval.ca (M.Y.) \\ 2 Department of Molecular Medicine, Faculty of Medicine, Laval University, Québec, QC G1V 0A6, Canada \\ * Correspondence: jonny.st-amand@crchudequebec.ulaval.ca; Tel.: +1-(418)-654-2296; Fax: +1-(418)-654-2761
}

Citation: Ghanemi, A.; Yoshioka, M.;

St-Amand, J. Measuring

Exercise-Induced Secreted Protein

Acidic and Rich in Cysteine

Expression as a Molecular Tool to Optimize Personalized Medicine.

Genes 2021, 12, 1832. https://

doi.org/10.3390/genes12111832

Academic Editor: Italia Di Liegro

Received: 6 October 2021

Accepted: 17 November 2021

Published: 20 November 2021

Publisher's Note: MDPI stays neutral with regard to jurisdictional claims in published maps and institutional affiliations.

Copyright: () 2021 by the authors. Licensee MDPI, Basel, Switzerland. This article is an open access article distributed under the terms and conditions of the Creative Commons Attribution (CC BY) license (https:// creativecommons.org/licenses/by/ $4.0 /)$.

\begin{abstract}
The numerous exercise benefits for health as well as applications for diseases has lead to exercise being prescribed in many pathological conditions. Secreted protein acidic and rich in cysteine (SPARC) gene expression is stimulated by exercise and SPARC has been suggested as a molecular mediator of exercise. Therefore, we suggest using this property for personalized medicine. This can be achieved by prescribing the exercise with a pattern (duration, intensity, etc.) that corresponds to the optimum SPARC/Sparc expression. We expect this approach to optimize the exercise therapy in both the preventive and curative contexts. In the research field, measuring exercise -dependent expression of Sparc would represent a molecular tool to further optimize the selection of exercise animal models as well.
\end{abstract}

Keywords: exercise; secreted protein acidic and rich in cysteine; expression; medicine

With the development of non-pharmacological and non-surgical approaches in therapeutics, the medical applications of exercise are gaining increasing importance. Indeed, beyond being a habit for numerous individuals with positive impacts on mood [1,2], exercise represents a therapeutic option for a variety of diseases and health conditions. It has been used within medical protocols either as a therapy or as an adjuvant to treat, prevent or improve diseases and health problems in which effects including controlling energy balance or enhancing biological properties are therapeutic targets such as cardiovascular diseases [3,4], obesity [5-8], low back pain [9], metabolic disorders [10], chronic kidney disease [11], regeneration [12], cancer [13], diabetes [14], immunity and infections [15-17]. Such exercise applications find their origin in the very numerous benefits that exercise has on health. This includes lowering blood pressure [18], bone osteogenesis stimulation [19], reducing cachexia [11] and anti-inflammatory effects [20]. Mental health (anxiety, stress and depression), sports psychiatry [21-23], and improved sleep quality [24,25] are also in this list. These medical benefits were considered as "granted" for humans who lived before the current industrial area because they had a healthier lifestyle that included sufficient physical activity. Thus, it significantly contributed to positive public health. However, in the last decades, the development of technologies has made life easier and humans need less effort to achieve what required huge effort previously. This situation has lead to a sedentary lifestyle and less active societies, which has contributed to the increase of various humans diseases. As an attempt to correct this negative consequence of modernity, health professionals are recommending physical activity for diverse population categories.

Regarding the molecular mechanism linking exercise and the exercise-induced effects, exercise benefits have been suggested to be mediated through a variety of factors, mainly the muscle-secreted myokines [26] that are produced by skeletal muscles and increase in response to exercise [27]. Such an exercise-induced pattern of secretion suggests that 
these myokines would govern the molecular pathways underlying the phenotypic changes resulting from exercise in different organs and tissues leading to the known health benefits of the physical activity. May be the most interesting one is secreted protein acidic and rich in cysteine (SPARC), an exercise-responsive myokine [28] in both humans and mice [29]. Indeed, using powerful functional genomics that represent a strong strategy to study the dynamic expression of genes [30,31], SPARC has been characterized as an exercise-induced gene [32]. Initially, the serial analysis of gene expression revealed that the cycle ergometer training increased the SPARC expression in muscles following endurance training [32]. Moreover, Aoi el al. showed that a single bout of exercise increased SPARC expression in the muscle and also in the plasma [29] and such a plasma exercise-induced increase becomes more important following training [29].

Following that, in vitro studies have been performed on $\mathrm{C} 2 \mathrm{C} 12$ muscle cells to further explore SPARC-exercise mechanistic links. Electrical pulse stimulation (EPS), considered as the in vitro model of exercise [33-36], applied on C2C12 cells also induced Sparc expression [37]. The same in vitro studies showed that Sparc modulates mitochondrial functions [37] and that adding SPARC both increased myoblasts differentiation and mitochondrial proteins in C2C12 cells [38]. Importantly, a recent in vivo study on trained Sparc knock-out mice suggested that exercise-induced muscle phenotype changes, including metabolism, strength and development, are SPARC-dependent [39]. Together, these data highlight SPARC as a key mediator of the exercise-induced benefits. Furthermore, the roles and functions in which SPARC has been implicated or suggested to be involved correlate with exercise effects. For instance, beyond its known implications, mainly in tissue repair [40], SPARC has been suggested to be involved in metabolic changes [28,41-44], bone formation [45], regeneration [46-48], anticancer effects [29,49], anti-inflammatory paths [50], and regulating muscle mass and function [51], all of which have also been shown to improve with exercise; which further supports the existence of molecular links between SPARC functions and exercise effects [28,52]. These cellular and molecular properties may represent the rationale why SPARC/Sparc functions as an exercise-responsive gene and why SPARC is induced by exercise. Indeed, since exercise may promote health and enhance systemic health via various cellular responses (e.g., metabolic change, bone, regeneration, anti-cancer, anti-inflammatory and regulation of muscle mass and function) that have been shown to implicate SPARC, SPARC comes out as a molecular mediator secreted following exercise to enhance and stimulate biological properties and endogenous processes toward a healthy homeostatic phenotype.

Therefore, since exercise effects are mediated via SPARC, the optimum exercise would be the one that induces SPARC/SPARC/Sparc expression the most. Thus, we suggest-for the first time to our knowledge-applying such a concept for personalized medicine. The process would be to challenge individuals with a variety of exercise patterns and programs that are different in terms of type of exercise type, the used device, the speed, duration, time (morning, night, etc.) and even the addition of other factors such as the temperature and incline setting (treadmill) for instance. Following the exercise, we proceed to a muscle biopsy, a common procedure [53,54], to measure the expression of SPARC/Sparc. Based on the results, the optimum exercise conditions (time, speed, environment, etc.) would be determined as those corresponding to the optimum SPARC/Sparc expression. Future studies, would allow one to make further links not only between exercise and SPARC/Sparc gene expression but also between the exercise and the protein SPARC expression or its serum levels that increase following exercise [29,55], thus adding the protein expression and the serum concentrations of SPARC as novel exercise-efficacy evaluation tools. Such tools would allow one to estimate the benefits that an exercise (depending on its patterns) would induce and open the door to a variety of potential applications (Figure 1). Measuring exercise-induced SPARC/SPARC/Sparc can contribute to answering the questions discussed in diverse studies in terms of exercise "dose" [14,56-58]. Indeed, a possible correlation between the exercise intensity and SPARC serum level has been shown [59], which supports such SPARC-dependent evaluation of exercise effects. 
Different exercise patterns: Type of exercise, training device, speed, duration, time (morning Vs night)
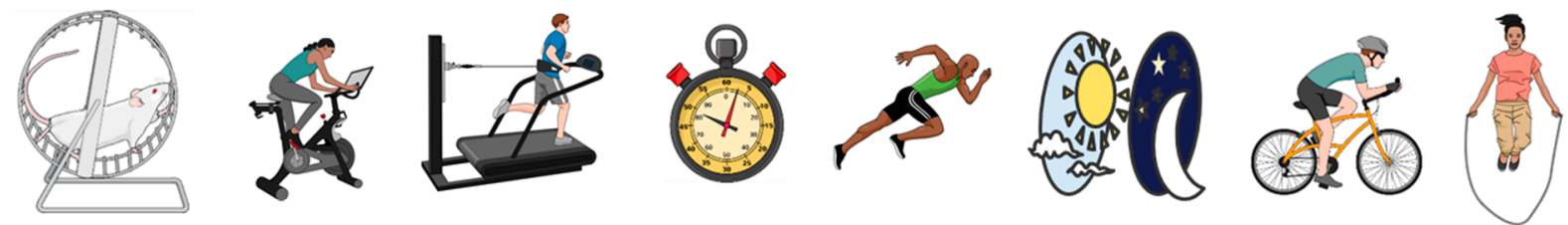

Variables-dependent exercise-induced secreted protein acidic and rich in cysteine
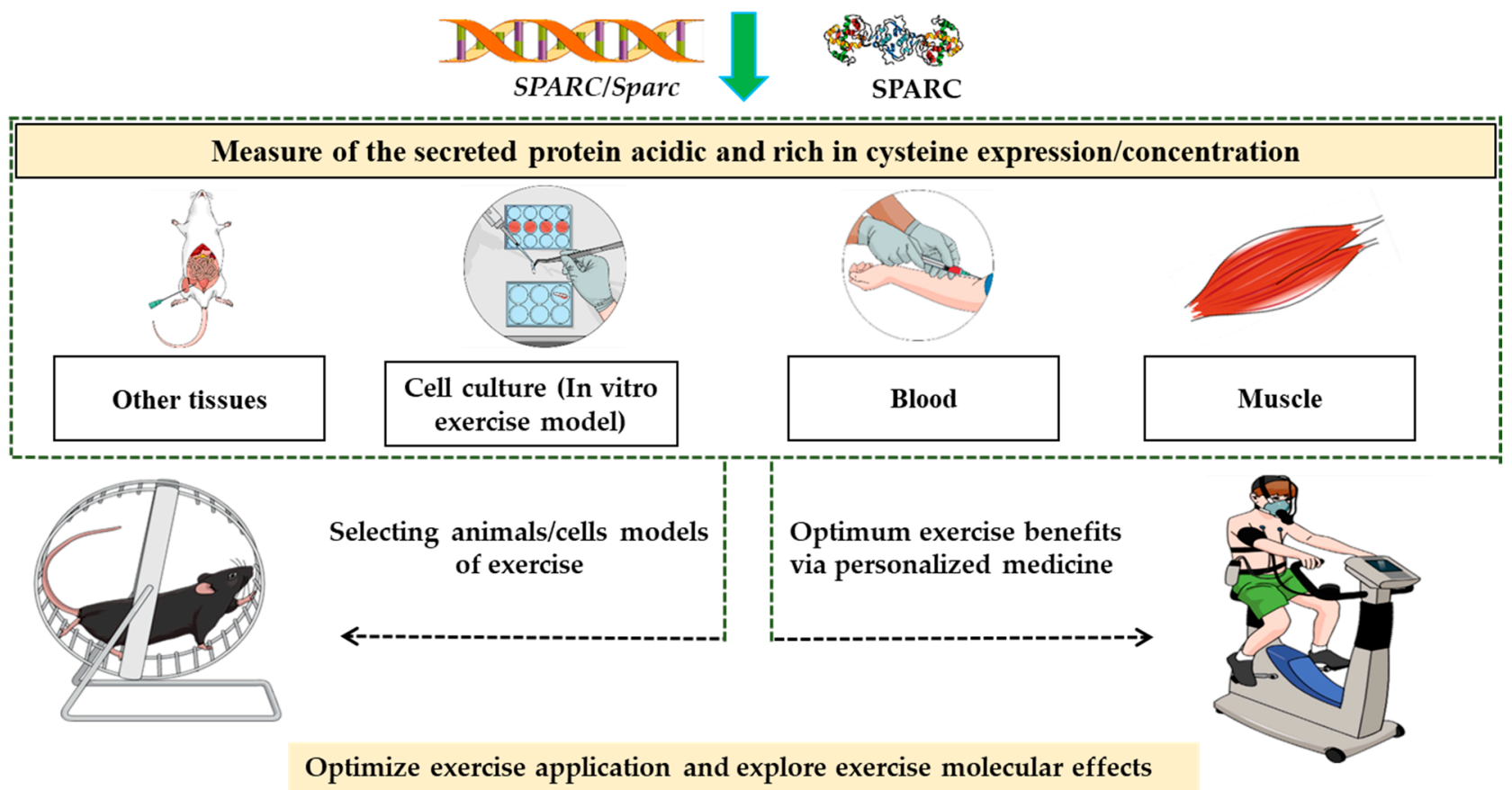

Figure 1. Measuring secreted protein acidic and rich in cysteine expression/concentration in biological samples following different patterns of exercise training would reflect the biological "responsiveness" to the physical activity and would predict the intensity of the benefits that exercise-induced changes will have. Such a property could be explored for instance to optimize the prescribed physical activity towards a personalized medicine approach and also select animal/cell models of exercise.

For clinical perspectives, which still require deeper investigations, the main application would be to determine the optimum parameters of the exercise to prescribe for patients suffering from diseases and health problems for which exercise represents a therapy. Of course, the tested exercise intensity, duration, strength, etc. would depend on each patient based on the physiological and biochemical parameters that limit the exercise ability such as oxygen saturation, lung capacity, heart status, glycemia and physical disabilities. Indeed, going beyond those physiological limits will not only be harmful but could also have no exercise-induced benefits, as suggested by the fact that supramaximal exercise had no effect on SPARC levels [60]. Such a need to set a limit could be achived by measuring SPARC via the evaluation of exercise-dependant SPARC expression as well.

Another application would be the optimization of animal models of exercise to better develop exercise science and exercise-related research towards an optimized application of exercise to treat patients, as a prevention for healthy individuals or to optimize training efficacy and outcome for athletes. Furthermore, the same SPARC/Sparc expression as a measure of exercise efficacy principle can be used not only to optimize the exercise pattern but also to compare different groups based on age, sex, diet, genetic polymorphism and species (animals). In this context, the in vitro models of exercise (electric pulse stimulation) would also provide additional data at the molecular and subcellular levels. 
The importance of such new tools comes from the fact that exercise represents a "panacea" for limitless health problems. We believe that this suggested approach of measuring of SPARC/SPARC/Sparc expression/level in response to different exercise patterns could optimize exercise science and provide molecular evaluation tools to significantly improve public health via personalized medicine. One of the main applications would be to manage obesity and metabolic disorders. This concept would also be of a specific application for the older population that have many potential benefits from exercise but that need to be optimized in terms of intensity, type and duration for healthy ageing [61-63].

The evidence we have provided builds up a puzzle that suggests SPARC as a selective biological marker that reflects the physiological responsiveness to exercise, not only through muscle-related patterns [64-67] but also metabolism [68], adiposity [69], and other effects, and thus the quality and the level of the induced benefits we will see following that exercise. However, further studies are still required to confirm and quantify the exact correlation between SPARC/SPARC expression and the various factors that define the exercise amount, mainly the intensity and the duration. These studies should focus on numerical and quantitative correlation similar to what we have for biomarkers used in clinical practice or biomedical research [70-87] including SPARC itself, which was also suggested as a physiological and pathological biomarker [88]. Personalized medicine [89-93] and precision medicine [94-101] are growing areas in respect to exercise [102-107], which further highlights the potential of measuring SPARC/SPARC/Sparc expression/level in optimizing and developing medical practice.

Author Contributions: A.G. designed the manuscript structure and wrote it. A.G., M.Y. and J.S.-A. discussed the content and exchanged ideas and suggestions (concepts to add, the figure, references selection, etc.) throughout the writing process, edited and critically revised the paper. J.S.-A. gave the final approval for the version to be published. All authors have read and agreed to the published version of the manuscript.

Funding: This work received no external funding.

Institutional Review Board Statement: Not applicable.

Informed Consent Statement: Not applicable.

Data Availability Statement: Not applicable.

Acknowledgments: Abdelaziz Ghanemi received a scholarship under the Merit Scholarship Program for foreign students from the Ministry of Education and Higher Education of Quebec, Canada. The Fonds de recherche du Québec-Nature et technologies (FRQNT) is responsible for managing the program (Bourses d'excellence pour étudiants étrangers du Ministère de l'Éducation et de l'Enseignement supérieur du Québec, Le Fonds de recherche du Québec-Nature et technologies (FRQNT) est responsable de la gestion du programme). Abdelaziz Ghanemi received the scholarship «Bourse Tremplin -Stage en milieu de pratique» (Internship scholarship) from the Fonds de recherche du Québec-Sante (FRQS), Quebec, Canada. Figure 1 was created using images from https:// mindthegraph.com/ (Accessed on 28 September 2021) and http:/ / smart.servier.com (Accessed on 28 September 2021). Servier Medical Art by Servier is licensed under a Creative Commons Attribution 3.0 Unported License.

Conflicts of Interest: The authors declare that there is no conflict of interest.

\section{References}

1. Hosker, D.K.; Elkins, R.M.; Potter, M.P. Promoting Mental Health and Wellness in Youth Through Physical Activity, Nutrition, and Sleep. Child. Adolesc. Psychiatr. Clin. N. Am. 2019, 28, 171-193. [CrossRef] [PubMed]

2. Peluso, M.A.; de Andrade, L.H.G. Physical activity and mental health: The association between exercise and mood. Clinics 2005, 60, 61-70. [CrossRef]

3. Myers, J.; McAuley, P.; Lavie, C.J.; Despres, J.P.; Arena, R.; Kokkinos, P. Physical activity and cardiorespiratory fitness as major markers of cardiovascular risk: Their independent and interwoven importance to health status. Prog. Cardiovasc. Dis. 2015, 57, 306-314. [CrossRef]

4. Katzmarzyk, P.T.; Ross, R.; Blair, S.N.; Després, J.P. Should we target increased physical activity or less sedentary behavior in the battle against cardiovascular disease risk development? Atherosclerosis 2020, 311, 107-115. [CrossRef] 
5. Ghanemi, A.; Yoshioka, M.; St-Amand, J. Obese Animals as Models for Numerous Diseases: Advantages and Applications. Medicina 2021, 57, 399. [CrossRef]

6. Ghanemi, A.; St-Amand, J. Redefining obesity toward classifying as a disease. Eur. J. Intern. Med. 2018, 55, 20-22. [CrossRef]

7. Ghanemi, A.; Yoshioka, M.; St-Amand, J. Broken Energy Homeostasis and Obesity Pathogenesis: The Surrounding Concepts. J. Clin. Med. 2018, 7, 453. [CrossRef]

8. Ghanemi, A.; Yoshioka, M.; St-Amand, J. Obesity as a Neuroendocrine Reprogramming. Medicina 2021, 57, 66. [CrossRef] [PubMed]

9. Owen, P.J.; Miller, C.T.; Mundell, N.L.; Verswijveren, S.; Tagliaferri, S.D.; Brisby, H.; Bowe, S.J.; Belavy, D.L. Which specific modes of exercise training are most effective for treating low back pain? Network meta-analysis. Br. J. Sports Med. 2020, 54, 1279-1287. [CrossRef]

10. Ghanemi, A.; Melouane, A.; Yoshioka, M.; St-Amand, J. Exercise and High-Fat Diet in Obesity: Functional Genomics Perspectives of Two Energy Homeostasis Pillars. Genes 2020, 11, 875. [CrossRef] [PubMed]

11. Wilkinson, T.J.; Shur, N.F.; Smith, A.C. “Exercise as medicine” in chronic kidney disease. Scand. J. Med. Sci. Sports 2016, 26, 985-988. [CrossRef]

12. Ghanemi, A.; Yoshioka, M.; St-Amand, J. Regeneration during Obesity: An Impaired Homeostasis. Animals 2020, 10, 2344. [CrossRef]

13. Idorn, M.; Straten, P.T. Exercise and cancer: From "healthy" to "therapeutic"? Cancer Immunol. Immunother. 2017, 66, 667-671. [CrossRef]

14. Balducci, S.; Sacchetti, M.; Haxhi, J.; Orlando, G.; D’Errico, V.; Fallucca, S.; Menini, S.; Pugliese, G. Physical exercise as therapy for type 2 diabetes mellitus. Diabetes Metab. Res. Rev. 2014, 30, 13-23. [CrossRef] [PubMed]

15. Simpson, R.J.; Kunz, H.; Agha, N.; Graff, R. Exercise and the Regulation of Immune Functions. Prog. Mol. Biol. Transl. Sci. 2015, 135, 355-380. [PubMed]

16. Ghanemi, A.; Yoshioka, M.; St-Amand, J. Coronavirus Disease 2019 (COVID-19) Crisis: Losing Our Immunity When We Need It the Most. Biology 2021, 10, 545. [CrossRef] [PubMed]

17. Ghanemi, A.; Yoshioka, M.; St-Amand, J. Will an obesity pandemic replace the coronavirus disease-2019 (COVID-19) pandemic? Med. Hypotheses 2020, 144, 110042. [CrossRef]

18. Sharman, J.E.; La Gerche, A.; Coombes, J.S. Exercise and cardiovascular risk in patients with hypertension. Am. J. Hypertens. 2015, 28, 147-158. [CrossRef] [PubMed]

19. Benedetti, M.G.; Furlini, G.; Zati, A.; Mauro, G.L. The Effectiveness of Physical Exercise on Bone Density in Osteoporotic Patients. Biomed. Res. Int. 2018, 2018, 4840531. [CrossRef]

20. Metsios, G.S.; Moe, R.H.; Kitas, G.D. Exercise and inflammation. Best Pract. Res. Clin. Rheumatol. 2020, 34, 101504. [CrossRef] [PubMed]

21. Ströhle, A. Sports psychiatry: Mental health and mental disorders in athletes and exercise treatment of mental disorders. Eur. Arch. Psychiatry Clin. Neurosci. 2019, 269, 485-498. [CrossRef]

22. Zhang, Y.; Zhang, H.; Ma, X.; Di, Q. Mental Health Problems during the COVID-19 Pandemics and the Mitigation Effects of Exercise: A Longitudinal Study of College Students in China. Int. J. Environ. Res. Public Health 2020, $17,3722$.

23. Mikkelsen, K.; Stojanovska, L.; Polenakovic, M.; Bosevski, M.; Apostolopoulos, V. Exercise and mental health. Maturitas 2017, 106, 48-56. [CrossRef]

24. Jurado-Fasoli, L.; De-la, O.A.; Molina-Hidalgo, C.; Migueles, J.H.; Castillo, M.J.; Amaro-Gahete, F.J. Exercise training improves sleep quality: A randomized controlled trial. Eur. J. Clin. Investig. 2020, 50, e13202. [CrossRef]

25. Yang, P.Y.; Ho, K.H.; Chen, H.C.; Chien, M.Y. Exercise training improves sleep quality in middle-aged and older adults with sleep problems: A systematic review. J. Physiother. 2012, 58, 157-163. [CrossRef]

26. Kwon, J.H.; Moon, K.M.; Min, K.-W. Exercise-Induced Myokines can Explain the Importance of Physical Activity in the Elderly: An Overview. Healthcare 2020, 8, 378. [CrossRef] [PubMed]

27. Aoi, W.; Sakuma, K. Skeletal muscle: Novel and intriguing characteristics as a secretory organ. BioDiscovery 2013, 7. [CrossRef]

28. Aoi, W.; Hirano, N.; Lassiter, D.G.; Björnholm, M.; Chibalin, A.V.; Sakuma, K.; Tanimura, Y.; Mizushima, K.; Takagi, T.; Naito, Y.; et al. Secreted protein acidic and rich in cysteine (SPARC) improves glucose tolerance via AMP-activated protein kinase activation. Faseb J. 2019, 33, 10551-10562. [CrossRef]

29. Aoi, W.; Naito, Y.; Takagi, T.; Tanimura, Y.; Takanami, Y.; Kawai, Y.; Sakuma, K.; Hang, L.P.; Mizushima, K.; Hirai, Y.; et al. A novel myokine, secreted protein acidic and rich in cysteine (SPARC), suppresses colon tumorigenesis via regular exercise. Gut 2013, 62, 882-889. [CrossRef]

30. Melouane, A.; Ghanemi, A.; Aubé, S.; Yoshioka, M.; St-Amand, J. Differential gene expression analysis in ageing muscle and drug discovery perspectives. Ageing Res. Rev. 2018, 41, 53-63. [CrossRef]

31. Melouane, A.; Ghanemi, A.; Yoshioka, M.; St-Amand, J. Functional genomics applications and therapeutic implications in sarcopenia. Mutat. Res. Rev. Mutat. Res. 2019, 781, 175-185. [CrossRef] [PubMed]

32. Riedl, I.; Yoshioka, M.; Nishida, Y.; Tobina, T.; Paradis, R.; Shono, N.; Tanaka, H.; St-Amand, J. Regulation of skeletal muscle transcriptome in elderly men after 6 weeks of endurance training at lactate threshold intensity. Exp. Gerontol. 2010, 45, 896-903. [CrossRef] [PubMed]

33. Scheler, M.; Irmler, M.; Lehr, S.; Hartwig, S.; Staiger, H.; Al-Hasani, H.; Beckers, J.; de Angelis, M.H.; Häring, H.U.; Weigert, C. Cytokine response of primary human myotubes in an in vitro exercise model. Am. J. Physiol. Cell Physiol. 2013, 305, C877-C886. [CrossRef] [PubMed]

34. Nikolić, N.; Bakke, S.S.; Kase, E.T.; Rudberg, I.; Halle, I.F.; Rustan, A.C.; Thoresen, G.H.; Aas, V. Correction: Electrical Pulse Stimulation of Cultured Human Skeletal Muscle Cells as an In Vitro Model of Exercise. PLoS ONE 2013, 8, e33203. [CrossRef] [PubMed]

35. Tarum, J.; Folkesson, M.; Atherton, P.J.; Kadi, F. Electrical pulse stimulation: An in vitro exercise model for the induction of human skeletal muscle cell hypertrophy. A proof-of-concept study. Exp. Physiol. 2017, 102, 1405-1413. [CrossRef] [PubMed] 
36. Feng, Y.Z.; Nikolić, N.; Bakke, S.S.; Kase, E.T.; Guderud, K.; Hjelmesæth, J.; Aas, V.; Rustan, A.C.; Thoresen, G.H. Myotubes from lean and severely obese subjects with and without type 2 diabetes respond differently to an in vitro model of exercise. Am. $J$. Physiol. Cell. Physiol. 2015, 308, C548-C556. [CrossRef]

37. Melouane, A.; Yoshioka, M.; Kanzaki, M.; St-Amand, J. Sparc, an EPS-induced gene, modulates the extracellular matrix and mitochondrial function via ILK/AMPK pathways in C2C12 cells. Life Sci. 2019, 229, 277-287. [CrossRef]

38. Melouane, A.; Carbonell, A.; Yoshioka, M.; Puymirat, J.; St-Amand, J. Implication of SPARC in the modulation of the extracellular matrix and mitochondrial function in muscle cells. PLoS ONE 2018, 13, e0192714. [CrossRef] [PubMed]

39. Ghanemi, A.; Melouane, A.; Yoshioka, M.; St-Amand, J. Exercise Training of Secreted Protein Acidic and Rich in Cysteine (Sparc) KO Mice Suggests That Exercise-Induced Muscle Phenotype Changes Are SPARC-Dependent. Appl. Sci. 2020, 10, 9108. [CrossRef]

40. Phan, E.; Ahluwalia, A.; Tarnawski, A.S. Role of SPARC-Matricellular protein in pathophysiology and tissue injury healing. Implications for gastritis and gastric ulcers. Med. Sci. Monit. 2007, 13, RA25-RA30.

41. Harries, L.W.; McCulloch, L.J.; Holley, J.E.; Rawling, T.J.; Welters, H.J.; Kos, K. A role for SPARC in the moderation of human insulin secretion. PLOS ONE 2013, 8, e68253. [CrossRef] [PubMed]

42. Hu, L.; He, F.; Huang, M.; Zhao, Q.; Cheng, L.; Said, N.; Zhou, Z.; Liu, F.; Dai, Y.S. SPARC promotes insulin secretion through down-regulation of RGS4 protein in pancreatic $\beta$ cells. Sci. Rep. 2020, 10, 17581. [CrossRef] [PubMed]

43. Ghanemi, A.; Melouane, A.; Yoshioka, M.; St-Amand, J. Secreted protein acidic and rich in cysteine and bioenergetics: Extracellular matrix, adipocytes remodeling and skeletal muscle metabolism. Int. J. Biochem. Cell Biol. 2019, 117, 105627. [CrossRef]

44. Ghanemi, A.; Yoshioka, M.; St-Amand, J. Secreted Protein Acidic and Rich in Cysteine: Metabolic and Homeostatic Properties beyond the Extracellular Matrix Structure. Appl. Sci. 2020, 10, 2388. [CrossRef]

45. Rosset, E.M.; Bradshaw, A.D. SPARC/osteonectin in mineralized tissue. Matrix Biol. 2016, 52-54, 78-87. [CrossRef]

46. Ghanemi, A.; Yoshioka, M.; St-Amand, J. Secreted Protein Acidic and Rich in Cysteine as A Regeneration Factor: Beyond the Tissue Repair. Life 2021, 11, 38. [CrossRef]

47. Petersson, S.J.; Jørgensen, L.H.; Andersen, D.C.; Nørgaard, R.C.; Jensen, C.H.; Schrøder, H.D. SPARC is up-regulated during skeletal muscle regeneration and inhibits myoblast differentiation. Histol. Histopathol. 2013, 28, 1451-1460.

48. Jørgensen, L.H.; Petersson, S.J.; Sellathurai, J.; Andersen, D.C.; Thayssen, S.; Sant, D.J.; Jensen, C.H.; Schrøder, H.D. Secreted protein acidic and rich in cysteine (SPARC) in human skeletal muscle. J. Histochem. Cytochem. 2009, 57, 29-39. [CrossRef]

49. Ghanemi, A.; Yoshioka, M.; St-Amand, J. Secreted protein acidic and rich in cysteine and cancer: A homeostatic hormone? Cytokine 2020, 127, 154996. [CrossRef] [PubMed]

50. Ghanemi, A.; Yoshioka, M.; St-Amand, J. Secreted protein acidic and rich in cysteine and inflammation: Another homeostatic property? Cytokine 2020, 133, 155179. [CrossRef] [PubMed]

51. Lee, J.H.; Jun, H.S. Role of Myokines in Regulating Skeletal Muscle Mass and Function. Front. Physiol. 2019, 10, 42. [CrossRef] [PubMed]

52. Kim, J.S.; Galvão, D.A.; Newton, R.U.; Gray, E.; Taaffe, D.R. Exercise-induced myokines and their effect on prostate cancer. Nat. Rev. Urol. 2021, 18, 519-542. [CrossRef]

53. Joyce, N.C.; Oskarsson, B.; Jin, L.W. Muscle biopsy evaluation in neuromuscular disorders. Phys. Med. Rehabil. Clin. N. Am. 2012, 23, 609-631. [CrossRef]

54. Pearl, G.S.; Ghatak, N.R. Muscle biopsy. Arch. Pathol. Lab. Med. 1995, 119, 303-306.

55. Garneau, L.; Parsons, S.A.; Smith, S.R.; Mulvihill, E.E.; Sparks, L.M.; Aguer, C. Plasma Myokine Concentrations After Acute Exercise in Non-obese and Obese Sedentary Women. Front. Physiol. 2020, 11, 18. [CrossRef] [PubMed]

56. Brown, J.C.; Damjanov, N.; Courneya, K.S.; Troxel, A.B.; Zemel, B.S.; Rickels, M.R.; Ky, B.; Rhim, A.D.; Rustgi, A.K.; Schmitz, K.H. A randomized dose-response trial of aerobic exercise and health-related quality of life in colon cancer survivors. Psychooncology 2018, 27, 1221-1228. [CrossRef] [PubMed]

57. Dunn, A.L.; Trivedi, M.H.; Kampert, J.B.; Clark, C.G. Chambliss HO: Exercise treatment for depression: Efficacy and dose response. Am. J. Prev. Med. 2005, 28, 1-8. [CrossRef]

58. Malliaras, P.; Johnston, R.; Street, G.; Littlewood, C.; Bennell, K.; Haines, T.; Buchbinder, R. The Efficacy of Higher Versus Lower Dose Exercise in Rotator Cuff Tendinopathy: A Systematic Review of Randomized Controlled Trials. Arch. Phys. Med. Rehabil. 2020, 101, 1822-1834. [CrossRef] [PubMed]

59. Miyamoto, T.; Shimizu, Y.; Matsuo, Y.; Otaru, T.; Kanzawa, Y.; Miyamae, N.; Yamada, E.; Katsuno, T. Effects of exercise intensity and duration on a myokine, secreted protein acidic and rich in cysteine. Eur. J. Sport Sci. 2021, 8, 1-10. [CrossRef] [PubMed]

60. Songsorn, P.; Ruffino, J.; Vollaard, N.B. No effect of acute and chronic supramaximal exercise on circulating levels of the myokine SPARC. Eur. J. Sport Sci. 2017, 17, 447-452. [CrossRef] [PubMed]

61. Galloza, J.; Castillo, B.; Micheo, W. Benefits of Exercise in the Older Population. Phys. Med. Rehabil. Clin. N. Am. 2017, 28, 659-669. [CrossRef]

62. Lee, P.G.; Jackson, E.A.; Richardson, C.R. Exercise Prescriptions in Older Adults. Am. Fam. Physician. 2017, 95, 425-432. [PubMed]

63. Baker, M.K.; Atlantis, E.; Singh, M.A.F. Multi-modal exercise programs for older adults. Age Ageing 2007, 36, 375-381. [CrossRef] [PubMed]

64. Nakamura, K.; Yamanouchi, K.; Nishihara, M. Transdisciplinary Approach for Sarcopenia. Molecular mechanism of sarcopenia: The role of skeletal muscle niche component SPARC in the regulation of myogenesis and adipogenesis and its alteration with age. Clin Calcium 2014, 24, 1471-1478.

65. Omi, S.; Yamanouchi, K.; Nakamura, K.; Matsuwaki, T.; Nishihara, M. Reduced fibrillar collagen accumulation in skeletal muscle of secreted protein acidic and rich in cysteine (SPARC)-null mice. J. Vet. Med. Sci. 2019, 81, 1649-1654. [CrossRef] [PubMed] 
66. Nakamura, K.; Yamanouchi, K.; Nishihara, M. Secreted protein acidic and rich in cysteine internalization and its age-related alterations in skeletal muscle progenitor cells. Aging Cell 2014, 13, 175-184. [CrossRef]

67. Nakamura, K.; Nakano, S.; Miyoshi, T.; Yamanouchi, K.; Matsuwaki, T.; Nishihara, M. Age-related resistance of skeletal muscle-derived progenitor cells to SPARC may explain a shift from myogenesis to adipogenesis. Aging (Albany NY) 2012, 4, 40-48. [CrossRef]

68. Song, H.; Ding, L.; Zhang, S.; Wang, W. MiR-29 family members interact with SPARC to regulate glucose metabolism. Biochem. Biophys. Res. Commun. 2018, 497, 667-674. [CrossRef]

69. Kos, K.; Wilding, J.P. SPARC: A key player in the pathologies associated with obesity and diabetes. Nat. Rev. Endocrinol. 2010, 6, 225-235. [CrossRef]

70. Pierrakos, C.; Vincent, J.L. Sepsis biomarkers: A review. Crit Care 2010, 14, R15. [CrossRef]

71. Capecchi, R.; Puxeddu, I.; Pratesi, F.; Migliorini, P. New biomarkers in SLE: From bench to bedside. Rheumatology (Oxford) 2020, 59, v12-v18. [CrossRef]

72. Kunc, P.; Fabry, J.; Lucanska, M.; Pecova, R. Biomarkers of Bronchial Asthma. Physiol. Res. 2020, 69, S29-S34. [CrossRef]

73. Aronson, J.K.; Ferner, R.E. Biomarkers-A General Review. Curr. Protoc. Pharmacol. 2017, 76, 9-23. [CrossRef] [PubMed]

74. Sandokji, I.; Greenberg, J.H. Novel biomarkers of acute kidney injury in children: An update on recent findings. Curr. Opin. Pediatr. 2020, 32, 354-359. [CrossRef]

75. Kawata, K.; Tierney, R.; Langford, D. Blood and cerebrospinal fluid biomarkers. Handb. Clin. Neurol. 2018, 158, 217-233. [PubMed]

76. Avramouli, A.; Vlamos, P. Buccal Mucosa Biomarkers in Alzheimer's Disease. Adv. Exp. Med. Biol. 2020, 1195, 49-56.

77. Zhou, L.T.; Lv, L.L.; Liu, B.C. Urinary Biomarkers of Renal Fibrosis. Adv. Exp. Med. Biol. 2019, 1165, 607-623.

78. Shen, L.; Liu, X.; Zhang, H.; Lin, J.; Feng, C.; Iqbal, J. Biomarkers in autism spectrum disorders: Current progress. Clin. Chim. Acta. 2020, 502, 41-54. [CrossRef] [PubMed]

79. Steckl, A.J.; Ray, P. Stress Biomarkers in Biological Fluids and Their Point-of-Use Detection. ACS Sens. 2018, 3, 2025-2044. [CrossRef]

80. Gururajan, A.; Clarke, G.; Dinan, T.G.; Cryan, J.F. Molecular biomarkers of depression. Neurosci. Biobehav. Rev. 2016, 64, 101-133. [CrossRef]

81. Watt, F.E. Osteoarthritis biomarkers: Year in review. Osteoarthritis Cartilage 2018, 26, 312-318. [CrossRef]

82. Chen, X.H.; Huang, S.; Kerr, D. Biomarkers in clinical medicine. IARC Sci. Publ. 2011, 303-322.

83. Jing, J.; Gao, Y. Urine biomarkers in the early stages of diseases: Current status and perspective. Discov. Med. 2018, $25,57-65$.

84. Agah, E.; Saleh, F.; Sanjari, M.H.; Saghazadeh, A.; Tafakhori, A.; Rezaei, N. CSF and blood biomarkers in amyotrophic lateral sclerosis: Protocol for a systematic review and meta-analysis. Syst. Rev. 2018, 7, 237. [CrossRef]

85. Bhide, A.A.; Cartwright, R.; Khullar, V.; Digesu, G.A. Biomarkers in overactive bladder. Int. Urogynecol. J. 2013, 24, 1065-1072. [CrossRef]

86. Ahn, M.H.; Kim, H.A. Biomarkers for adult-onset still's disease: Up-to-date. Expert. Rev. Mol. Diagn. 2019, 19, 655-657. [CrossRef] [PubMed]

87. Zhao, X.; Modur, V.; Carayannopoulos, L.N.; Laterza, O.F. Biomarkers in Pharmaceutical Research. Clin. Chem. 2015, 61, 1343-1353. [CrossRef] [PubMed]

88. Ghanemi, A.; Yoshioka, M.; St-Amand, J. Secreted Protein Acidic and Rich in Cysteine as a Molecular Physiological and Pathological Biomarker. Biomolecules 2021, 11, 1689. [CrossRef]

89. Curigliano, G. Personalizing medicine through personalized communication: Individuality of the patient across borders and cultures. J. Natl. Compr. Canc. Netw. 2010, 8, 277-278. [CrossRef]

90. Ziegelstein, R.C. Perspectives in Primary Care: Knowing the Patient as a Person in the Precision Medicine Era. Ann. Fam. Med. 2018, 16, 4-5. [CrossRef]

91. Erden, A. Personalized Medicine: How Studying Individual Differences Can Shed Light on Treating Thousands of Patients: An Interview with Richard Lifton, PhD. Yale. J. Biol. Med. 2015, 88, 407-411.

92. Abettan, C.; Welie, J.V.M. The impact of twenty-first century personalized medicine versus twenty-first century medicine's impact on personalization. Philos. Ethics Humanit Med. 2020, 15, 11. [CrossRef] [PubMed]

93. Boersma, G.J.; Benthem, L.; van Beek, A.P.; van Dijk, G.; Scheurink, A.J. Personality, a key factor in personalized medicine? Eur. J. Pharmacol. 2011, 667, 23-25. [CrossRef] [PubMed]

94. Khatri, V.P.; Petrelli, N.J. Precision Medicine. Surg. Oncol. Clin. N. Am. 2020, 29, xv-xvi. [CrossRef] [PubMed]

95. Ramaswami, R.; Bayer, R.; Galea, S. Precision Medicine from a Public Health Perspective. Annu. Rev. Public Health 2018, 39, 153-168. [CrossRef]

96. Beckmann, J.S.; Lew, D. Reconciling evidence-based medicine and precision medicine in the era of big data: Challenges and opportunities. Genome Med. 2016, 8, 134. [CrossRef]

97. Antman, E.M.; Loscalzo, J. Precision medicine in cardiology. Nat. Rev. Cardiol. 2016, 13, 591-602. [CrossRef] [PubMed]

98. Weil, A.R. Precision Medicine. Health Aff. (Millwood) 2018, 37, 687. [CrossRef]

99. Xie, F.; Chan, J.C.; Ma, R.C. Precision medicine in diabetes prevention, classification and management. J. Diabetes Investig. 2018, 9 , 998-1015. [CrossRef]

100. Forrest, S.J.; Geoerger, B.; Janeway, K.A. Precision medicine in pediatric oncology. Curr. Opin. Pediatr. 2018, 30, 17-24. [CrossRef] [PubMed]

101. König, I.R.; Fuchs, O.; Hansen, G.; von Mutius, E.; Kopp, M.V. What is precision medicine? Eur. Respir. J. 2017, 50. [CrossRef]

102. Yardley, J.E.; Campbell, M.D. Moving Toward Precision Medicine with Diabetes, Exercise and Physical Activity. Can. J. Diabetes 2020, 44, 679. [CrossRef] [PubMed]

103. Bonafiglia, J.T.; Ramic, L.; Islam, H. Challenges to personalized exercise medicine: Lack of repeatability and influence of genetics. J. Physiol. 2020, 598, 5021-5023. [CrossRef] [PubMed]

104. Buford TW, Roberts MD, Church TS: Toward exercise as personalized medicine. Sports Med. 2013, 43, 157-165. [CrossRef] [PubMed] 
105. Garner, S.; Fenton, T.; Martin, L.; Creaser, C.; Johns, C.; Barnabe, C. Personalized diet and exercise recommendations in early rheumatoid arthritis: A feasibility trial. Musculoskeletal Care 2018, 16, 167-172.

106. Kostek, M. Precision Medicine and Exercise Therapy in Duchenne Muscular Dystrophy. Sports (Basel) 2019, 7, 64. [CrossRef]

107. Ross, R.; Goodpaster, B.H.; Koch, L.G.; Sarzynski, M.A.; Kohrt, W.M.; Johannsen, N.M.; Skinner, J.S.; Castro, A.; Irving, B.A.; Noland, R.C.; et al. Precision exercise medicine: Understanding exercise response variability. Br. J. Sports Med. 2019, 53, $1141-1153$. [CrossRef] 